Syntax Literate: Jurnal Ilmiah Indonesia p-ISSN: 2541-0849

e-ISSN: 2548-1398

Vol. 6, No. 1, Januari 2021

\title{
ANALISIS SWOT SEBAGAI STRATEGI DALAM MEMBANTU PEREKONOMIAN UMKM JASA KONVEKSI@ANFCREATIVE.ID DI ERA PANDEMI
}

\author{
Ashif Jauhar Winarto \\ Pasca Sarjana Ekonomi Syariah UIN Sunan Ampel Surabaya, Indonesia \\ Email: ashifjauhar@gmail.com
}

\begin{abstract}
This study aims to know the economy of UMKM sector during pandemic. This study was conducted at the @anfcreative.id convection service, located in Jombang, East Java. For the management of UMKM, the @ anfcreativ.id convection service creates empowerment to the people living around the location by employing local communities. In this study, the researchers explained product marketing strategy and analyze it, in terms of internal and external environmental problems. Method of this study used descriptive qualitative methods, of which the researchers collected data related to this research and information that supports the research discussion. The interview focused on 3 elements, such as owners, employees and buyers of the convection service. Observations were carried out directly in the location. The results of interviews and observations were grouped by analysis of internal and external environmental factors, which were linked into an internal-external matrix, SWOT matrix. The results of the analysis of internal and external factors were more inclined on the strategy (SO) or strength and opportunities, so that it can be concluded that UMKM convection service @anfcreative.id continue to expand market share and to open employment opportunities for local residents, so that the local residents can maintain or even increase their household economy at maximum during pandemic.
\end{abstract}

Keywords: product marketing; UMKM management; pandemic

\begin{abstract}
Abstrak
Penelitian ini bertujuan untuk mengetahui strategi dalam membantu perekonomian sektor UMKM di era pandemi. Penelitian dilakukan di jasa konveksi @anfcreative.id tepatnya di Jombang, Jawa Timur. Dalam pengelolaan UMKM seperti jasa konveksi @anfcreativ.id memberikan pemberdayaan pada masyarakat yang berada disekitar lokasi dengan cara memperkerjakan masyarakat tersebut. Dalam penelitian ini, peneliti akan menjelaskan strategi pemasaran produk dan menganalisisnya baik dalam masalah lingkungan internal atau eksternal. Penelitian ini menggunakan metode kualitatif deskriptif. Yang mana peneliti akan mencari data yang berhubungan dengan penelitian, adapun informasi yang mendukung pada pembahasan penelitian. Wawancara di fokuskan pada 3 unsur yakni pemilik atau owner dari jasa konveksi, karyawan jasa konveksi dan pembeli produk dari jasa konveksi. Observasi dilakukan secara langsung ke lokasi. Hasil wawancara dan observasi dikelompokan dengan analisis faktor lingkungan internal dan eksternal,
\end{abstract}


kemudian menghubungkan kedalam bentuk matriks internal eksternal, matriks swot. Yang mana hasil dari penelitian ini dalam analisis faktor internal dan eksternal lebih condong kepada strategi (SO) atau kekuatan (strength), Peluang (opportunites) yang mana dapat disimpulkan bahwa UMKM jasa konveksi @anfcreative.id bisa terus melakukan ekspansi pangsa pasar dan juga terus membuka lapangan pekerjaan bagi warga sekitar sehingga warga sekitar bisa mempertahankan ekonomi rumah tangganya dengan maksimal di era pandemi.

Kata Kunci: pemasaran produk; pengelolaan UMKM; pandemi

Coresponden Author

Email: ashifjauhar@gmail.com Artikel dengan akses terbuka dibawah lisensi

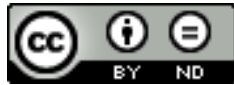

\section{Pendahuluan}

Pertumbuhan ekonomi dapat dilihat dari beberapa indikator yakni dari perkembangan ekonomi di setiap daerah, bangsa dan negara, atas dasar tersebut maka daerah, bangsa dan negara merupakan elemen penting untuk mengatur regulasi ekonomi. Pada saat ini Indonesia mengalama kondisi dimana tingkat kependudukan usia produktif semakin meningkat, jika hal ini tidak diimbangi dengan kegiatan atau pola pikir yang positif seperti memulai berfikir kreatif untuk menciptakan sebuah lapangan usaha, agar masyarakat di negara ini tidak mengalami keterpurukan nasib dikarenakan semakin banyak usia produktif yang tidak bekerja atau menambah angka pengangguran hal ini sangat bersifat negatif dan mempengaruhi sektor perekonomian, seperti halnya sempitnya lapangan perkerjaan jika tidak membuat usaha badan milik sendiri dan angka pengangguran akan terus bertambah. Oleh sebab itu masyarakat dituntut untuk membuat lapangan pekerjaan sendiri walaupun lingkupnya kecil atau bisa dibilang Usaha Mikro Kecil Menengah (UMKM).

Keberadaan UMKM tidak bisa dihapuskan ataupun dihindarkan dari masyarakat negara saat ini. Karena keberadaan UMKM mempunyai peran yang sangat penting dalam mempertahankan perekonomian nasional, dan juga sangat bermanfaat dalam hal pendistribusian pendapatan bagi masyarakat. Selain itu UMKM mampu menciptakan ide atau gagasan kreatif yang searah dengan tujuan maupun harapan usaha untuk mempertahankan dan mengembangkan tradisi juga kebudayaan setempat. Di dalam pandangan lain bahwa UMKM juga memiliki potensi untuk meningkatkan perekonomian dan kemakmuran masyarakat dikarenakan semakin banyak UMKM maka semakin banyak juga lapangan pekerjaan mengingat jumlah penduduk di negara ini sangatlah banyak sehingga bisa mengurangi angka pengangguran. Dari sini bisa dilihat bahwa adanya sektor UMKM yang bersifat padat karya, menggunakan teknologi yang sederhana dan mampu dipahami sehingga masyarakat mudah untuk berkerja.

Didalam perkonomian negara saat ini mengalami penurunan produk domestik bruto (PDB) dikarenakan situasi dan kondisi yang kurang menjamin dilandanya 
pandemi covid-19. Bukan hanya dinegara Indonesia melainkan banyak negara tetangga juga yang mengalami penurunan pendapatan negara yang disebabkan adanya pandemi covid-19. Oleh sebab itu pemerintah memberikan perhatian cukup besar terhadap sektor UMKM, karena pendapatan untuk negara cukup besar dalam perekonomian di Indonesia. Berdasarkan data kementerian koperasi dan UMKM ada sekitar 99\% unit usaha di Indonesia adalah UMKM, terdiri dari 6,702 usaha menengah, 783,132 usaha kecil, dan 63,5 juta usaha mikro (Purwanto, 2020). Kontribusi UMKM terhadap produk domestik bruto (PDB) nasional sangatlah besar yakni 60,3\%. Sehingga UMKM menjadi perhatian khusus dalam kondisi seperti ini. Dalam situasi pandemi covid-19, justru potensi UMKM menguasai pasar saat pandemi sangatlah besar, terutama bisa dilihat bahwa saat ini sektor impor tidak lagi berjalan seperti sediakala atau pada saat situasi normal. Sehingga sektor UMKM hadir untuk memberikan warna kreatifitas tehadap produk yang dijual baik lingkup daerah maupun nasional.

Hal ini menjadi tuntutan kepada sektor UMKM agar terus menjadi garda terdepan untuk menginisiasi sebuah pola pikir kreatif terhadap produksi maupun pemasaran di sektor UMKM. Bagaimana diketahui bahwa pandemi covid-19 ini sangatlah mengancam perekonomian dari sektor manapun, oleh sebab itu UMKM harus berpikiran kreatif seperti halnya memasarkan produk yang awalnya bisa dipasarkan secara langsung atau ditempat, tetapi saat ini hanya bisa dipasarkan melalui media online. Masyarakat Indonesia yang bergelut di sektor UMKM harus memiliki pola pikir yang maju sehingga bisa mengaplikasikan media online untuk dimanfaatkan dengan sebaik-baiknya seperti halnya menjual sebuah produk. Agar pada saat pandemi sektor UMKM tidak berhenti beroperasi tapi terus beroperasi dengan pola pikir yang awalnya primitif menjadi kreatif sehingga menimbulkan input omset yang terus mengalami peningkatan walaupun ditengah pandemi saat ini.

Ketahanan sektor UMKM untuk membantu perekonomian pada saat pandemi merupakan isu yang sangat sentral dan menjadi domain utama salah satu UMKM yang berada di Kabupaten Jombang, khususnya UMKM yang bergerak dibidang jasa konveksi seperti@anfcreative.id yang sudah menggeluti sektor UMKM sejak tahun 2017. @anfcreative.id merupakan salah satu UMKM yang berada di Kabupaten Jombang fokus untuk memproduksi seperti pakaian fashion baik laki-laki ataupun perempuan. Letak dari pada jasa konveksi ini yakni berada di Jl. Raya Jombok, Kabupaten Jombang, Jawa Timur. Jasa Konveksi @anfcreative.id memiliki 6 karyawan yang terbagi tugasnya masing-masing yakni 2 orang bertugas untuk menjahit kain untuk dijadikan baju, 2 orang bertugas untuk menyablon ketika baju sudah dijahit, dan 2 orang bertugas merapikan juga mengemasi barang atau packaging. UMKM ini memperkerjakan masyarakat disekitarnya yang belum memiliki pekerjaan sehingga mereka terbantu dalam perekonomian rumah tangganya masing-masing melalui penghasilan yang didapat saat berkerja. Dan owner sendiri juga ikut berkontribusi penuh mengatur segala regulasi keuangan dan membantu dalam sistem pemasaran produk baik via online ataupun offline. Hal ini menciptakan sebuah keharmonisan dalam usaha di sektor UMKM dikarenakan tumpoksi tanggung jawab bekerja yang jelas dan 
mengentaskan kemiskinan di Indonesia. Di era pandemi @anfcreative.id justru yang seharusnya sangat berdampak mengalami kemerosotan pendapatan tetapi malah sebaliknya UMKM ini bisa bertahan dan terus bertambah omsetnya setiap bulannya.

Untuk itu dalam mengetahui langkah strategi yang di gunakanan dalam UMKM jasa konveksi ini diperlukan dalam menganalisis baik dari sektor internal ataupun eksternal, dengan begitu akan mengetahui dengan analisis SWOT yang dimana mengetahui kekuatan, kelemahan, peluang dan tantangan dalam mempertahankan sebuah UMKM yang telah berjalan di era pandemi ini. Menurut Rangkuti (2008:19), kinerja perusahaan ataupun organisasi dapat ditentukan oleh kombinasi faktor internal dan eksternal. Sehingga bisa mengetahui pola regulasi produksi UMKM jas konveksi ini dan bisa memperkerjakana para karyawan dengan jumlah tertentu dan dengan gaji yang berkelanjutan masih bisa diterapkan seperti bisa pada saat sebelum era pandemi ini. Juga terus bisa memproduksi dan menjualkan produk dengan maskimal di saat era pandemi ini banyak diketahui bahwa sektor UMKM yang saat ini bekerja hanyalah sedikit dikarenakan momentum dengan virus covid-19 ini sehingga tidak bisa beroperasi lagi.

Berdasarkan fenomena tersebut timbulah pertanyaan bagaimana sistem manajemennya, bagaimana sistem pemasarannya, bagaimana sistem penerimaan tenaga kerjanya, bagaimana sistem produksinya, juga bagaimana bisa produk UMKMnya bisa bertahan di tengah pandemi ini, dll. Tujuan yang ingin dicapai dalam penelitian ini ialah mengidentifikasi faktor strategis eksternal dan internal jasa konveksi @anfcreative.id dalam strategi membantu perekonomian di era pandemi. Adapaun tujuan analisis menggunakan analisis SWOT pada UMKM untuk memberikan suatu pandangan agar UMKM menjadi lebih fokus, sehingga dalam penempatan analisis SWOT bisa dijadikan sebagai pembanding pikir dari berbagai sudut pandang, baik dari padangan kekuatan ataupun kelemahan serta peluang dan ancaman (Fahmi, 2015). Manfaat dalam menggunakan analisis SWOT yakni bisa mengetahui strategi yang pantas dalam penerapan pemasaran dan bisa menjadi acuan rekomendasi peluang untuk menghadapi pangsa pasar juga mengetahui kelemahan yang ada di UMKM tersebut sehingga bisa terus memperbaiki kesalahan yang sebelumnya, dan menjadikan UMKM terus progres di era pandemi ini. Dalam hal ini UMKM jasa konveksi @anfcreative.id yang mana awalnya masih belum menggunakan metode analisis SWOT sehingga pada penelitian ini memberikan kebaharuan dan rekomendasi strategi agar UMKM terus bisa mengembangkan pangsa pasar dan meningkatkan omset untuk membantu perekonomian di masa pandemi.

\section{Metode Penelitian}

Metode penelitian ini menggunakan metode kualitatif deskriptif. Menurut (Sugiyono, 2011), bahawasannya metode kualitatif ini guna menggambarkan juga memahami arti di balik data-data yang tampak. Juga dijelaskan bahwasannya metode ini lebih mengarahkan kepada penelitian deskriptif. Dengan sedemikian rupa penelitian kualitatif deskriptif bisa menggambarkan serta memberikan pemahaman terhadap 
realitas yang kompleks. Oleh sebab itu peneliti disini akan memberikan gambarangambaran yang kompleks tentang kondisi dimana UMKM menjadi solusi atau hal yang bisa menjadi acuan dalam membantu perekonomian dimasa pandemi dan juga akan mendeskripsikan tentang UMKM jasa konveksi @anfcreative.id di Jombang yang akan diteliti. Tekni analisis data ialah proses penyusunan data agar data tersebut dapat di tafsirkan (Ahmad, 2000).

Untuk membuat deskripsi ataupun memberikan gambaran tekait dengan penelitian ini maka peneliti menggunakan teknik pengumpulan data yakni data yang digunakan meliputi data sekunder dan data primer. Data sekunder disini meliputi, profil dari pada UMKM jasa konveksi @anfcreative.id, strategi pemasaran dan jumlah pasar. Pengumpulan data ini dilakukan dengan menggunakan data yang tertulis yang diperoleh dari berbagai sumber yang berkaitan dengan tujuan penelitian. Data primer diperoleh dari wawancara dan observasi pengamatan langsung di lapangan. Wawancara disini dilakukan secara langsung dengan dengan melontarkan pertanyaan yang berhubungan erat dengan tujuan penelitian. Wawancara dilakukan kepada beberapa responden guna memperoleh data yang dibutuhkan oleh peneliti dalam penelitian ini. Untuk itu responden dalam penelitian ini terdiri dari 12 orang, meliputi beberapa unsur yakni 1 owner pemilik dari UMKM @anfcreative.id, 6 karyawan yang bekerja di UMKM jas konveksi tersebut yang sekaligus juga warga sekitar, dan 5 konsumen yang pernah melakukan transaksi di @anfcreative.id.

Dalam membantu untuk mendapatkan data yang akurat, diperlukan instrumen penelitian yang bisa membantu atau alat bantu seperti draf pertanyaan yang sesuai dengan tujuan penelitian. Selain itu instrumen lain yakni berupa kamera digital, tape recoder untuk merekam suara dan gambar dari responden, juga yang pasti adalah pedoman wawancara (Interview guideline) yang digunakan dalam pengumpulan data.

Untuk menginventarisir berbagai padangan atau pendapat tentang isi dari setiap aspek SWOT untuk kasus tertentu (Jazuli, 2016). Jadi setelah data sudah terkumpul maka peneliti akan menganalisis guna memperoleh mengenai tujuan penelitian seperti startegi pemasaran yang digunakan dalam mencapai target penjualan, jumlah dari pasar atau pangsa pasar siapa saja dan bagaimana respon pangsa pasar terhadap produk, dengan cara menggunakan Analisis SWOT. Kinerja perusahaan ataupun organisasi dapat ditentukan oleh kombinasi faktor internal dan eksternal (Rusdiansyah, 2016). Kedua faktor tersebut harus dipertimbangkan dalam analisis SWOT. Oleh sebab itu peneliti dalam kinerja dari UMKM jasa konveksi @anfcreative.id ini bisa membantu perekonomian di masa pandemi dapat ditentukan oleh kombinasi faktor eksternal dan internal yang dipertimbangkan dalam analisis SWOT. Analisis SWOT ialah sebuah cara untuk mengidentifikasi beberapa faktor secar sistemastis guna merumuskan strategi perusahaan analisis SWOT didasarkan pada logika dapat memaksimalkan kekuatan, dan peluang, namun secara bersamaan dapat meminimalkan kelemahan dan acaman (Marimin, 2004). Guna dari analisis SWOT yakni membandingkan antara faktor-faktor internal yang merupakan strengths (kekuatan) dan weaknesses (kelemahan) dengan faktor-faktor eksternal yang merupakan opportunities (peluang) dan threats (ancaman). 
Gabungan antara faktor internal dengan eksternal yakni strategi SO (Strengths Opportunities) dalam strategi ini perusahaan mempunyai peluang dan kekuatan secara maksimal sehingga bisa meningkatkan produksi ataupun kinerja. Strategi ST (Strengths Threats) dalam hal ini walaupun perusahaan mengahadapi ancaman yang berbagai akan tetapi perusahaan masih memilki keunggulan sehingga masih bisa terus produksi. Strategi WO (Weaknesses Opportunities) terkait dengan ini perusahaan mengalami peluang pasar yang sangat besar hanya saja pekerja atau sdm dalam perusahaan tersebut lemah. Strategi WT (Weaknesses Threats) yakni kondisi dimana perusahan tidak bisa melanjutkan produksi dikarenakan ancaman dan kelemahan yang komplit.

\section{Hasil dan Pembahasan}

Usaha Mikro, Kecil, Menengah (UMKM) merupakan badan usaha milik perorangan yang bisa memperluas dan membuka lapangan pekerjaan juga memberikan pelayan ekonomi secara luas kepada masyarakat yang di Indonesia baik di plosok negeri maupun di perkotaan (Jatmika, 2017). UMKM memiliki peran yang sangat sentral dalam pendapatan negara atau produk domestik bruto (PDB) dikarenakan sektor ini memberikan kontribusi 60,3\% terhadap pendapatan negara. Untuk itu UMKM juga memilki peran lain yakni dalam proses pemerataan dan peningkatan pendapatan masyarakat tersendiri atau ekonomi rumah tangga, dengan tujuan lain sektor ini juga sangat berdampak dalam mendorong pertumbuhan perekonomian, dan juga mewujudkan stabilitas perekonomian nasional.

Pada tahun 2008 pemerintah mengesahkan undang-undang tersendiri khusus untuk sektor UMKM. Yang dimana Undang-Undang Republik Indonesia tercatat di Nomor 20 Tahun 2008 tentang Usaha Mikro, Kecil, dan Menengah yang pada saat itu disahkan oleh Presiden Dr. H. Susilo Bambang Yudhoyono tepatnya pada tanggal 4 Juli 2008 di Jakarta. Dalam ini, UMKM menjadi salah satu pilar utama ekonomi nasional yang sangat diperhatikan oleh pemerintah dan haru mendapatkan kesempatan utama, dukungan, perlindungan, dan pengembangan yang seluas-luasnya sebagai bentuk untuk berpihak dengan tegas kepada kelompok usaha ekonomi rakyat, tanpa melupakan peran yang diberikan usaha besar ataupun badan milik usaha.

Berawal dari tahun 2008 dimana sudah disahkannya undang-undang tentang UMKM, program pemerintah dalam sektor pengawasan UMKM kini semakin bekembang dan terus di dorong untuk perekonomian nasional. Banyak yang sudah mengetahu pada saat ini seluruh sektor perekonomian baik negara Indonesia ataupun negara tetangga mengalami keterpurukan dikarenakan adanya virus covid-19.

Dalam situasi pandemi ini pemerintah juga tidak melepas kendali terhadap sektor UMKM yang dimana sangat berdampak pada pendapatan negara sehingga pemerintah terus membuat trobosan agar para pelaku UMKM tidak mengalami keterpurukan walaupun sudah banyak yang tutup buku dalam menjalanankan usahanya saat ini dikarenakan pandemi yang belum tau kapan berkesudahan.

Pada saat pandemi seperti ini untuk mempertahankan sektor UMKM pemerintah membuat kebijakan yakni Pemulihan Ekonomi Nasioanl (PEN), dimana kebijakan ini 
memberikan dampak yang positif dari sebelumnya mayoritas pelaku UMKM hanya memiliki modal usaha kurang dari tiga bulan, sedangkan saat ini dengan adanya program PEN bisa menambah modal kerja lebih dari empat bulan. Hal ini tentunya sangat berguna untuk mempertahankan kelangsungan operasi sektor UMKM. Terdapat salah satu UMKM yang mana pada tahun 2017, berdiri salah satunya UMKM yang ada di Jawa Timur tepatnya di Kabupaten Jombang dengan fokus UMKMnya yakni jasa konveksi@anfcreative.id. Walaupun sudah berdiri sejak tahun 2017 UMKM ini terus mengalami progres baik dalam manajemennya ataupun pendapatan setiap bulannya. Hingga pada saat kondisi pandemi UMKM ini terus beroperasi dan mempertahankan omset juga berusaha untuk meningkatkan omset setiap bulannya.

UMKM jasa konveksi @anfcreative.id sudah berdiri kurang lebih selama 4 tahun, pada fase itu juga memiliki pengalaman untuk peningkatkan produksi hingga seperti pada saat ini. Terdapat didalam UMKM tersebut struktur organisasinya yakni mulai dari president director atau pemilik badan usaha oleh Agik Nurfayi yang memiliki beberapa karyawan diantaranya, managing director atau yang bertuga memanajemen terhadap sistem produksi juga penjualan oleh Zainul Affan, cutting division atau bertugas untuk divis pemotongan kain untuk dijadikan sebuah produk seperti baju disini yang bertuga bernama Oky Yudha Prasetyo, printing supervisior atau yang bertugas menyablon mencetak sebuah produk untuk dijualkan yakni Jefry Iffah, operator jahit yang terdapat 3 orang yakni Neneg, Suharti dan Sri, dan yang terakhir packing steam atau yangg bertugas untuk mengemasi produk yang sudah jadi dan dikirimkan ke konsumen yakni Rupi'ah. Dalam jasa konveksi @anfcreative.id fokus pada pembuatan baju baik lakilaki ataupun perempuan dengan printting yang sesuai pesanan dari konsumen. Sistem pembagian gaji terhadap karyawan yakni dengna sistem gaji total diakhir yang dikerjakan atau yang diproduksi sebuah produknya sabagaimana pada gaji karyawan 1 produksi baju dengan gaji 3000 jika dikalikan 500 baju maka gaji setiap bulan dari karyawan tersebut 1,5 juta ini untuk karyawan yang fokus pada pembuatan baju atau penjahitan baju. Dan untuk karyawan yang fokus dengan printting 1 produksi dengan gaji 2000 jika dikalikan 500 baju maka gaji setiap bulannya menjadi 1 juta. Begitu juga dengan yang khusus bertugas untuk merapikan baju atau dengan menyeterika yakni dengan gaji 45 ribu perhari dan dalam satu bulan membutuhkan 15 hari kerja yakni dalam satu bulan mendapatkan gaji 675 ribu. Dan keuntungan bersih yang didapatkan kurang lebih berkisar 5-7 juta setiap bulannya dalam produksi setiap bulannya 500 unit baju konveksi (Nurfayi, 2021).

Produksi pada UMKM jasa konveksi @anfcreativ.id yang tepatnya berada di Kabupaten Jombang, Provinsi Jawa Timur, pada saat kondisi pandemi.

\section{a. Kegiatan produksi}

William J. Stanton (1981) (dalam Muhsy, 2020) mendefinisikan produk secara khusus dan umum. Secara khusus produk adalah sebuah bentuk fisik yang nyata sedangkan secara umum produk dapat diartikan barang yang nyata atau tidak nyata, ini mencangkup nama, harga, kemasan, prestise pengecer dan pelayan pihak pabrik dan pengecer terhadap penliaian baik dan kepuasan pembeli. Dalam kegiatan 
produksi UMKM jasa konveksi @anfcreative.id ini memproduksi produk dengan sendirinya, karena bisa dilihat dalam observasi langsung saat peneliti langsung berad di lokasi yang diteliti, UMKM ini sudah memilki mesin untuk produksi kaos seperti alat jahit untuk menjahit baju, hanya saja untuk membuat baju pasti dibutuhkan kain dan kain ini masih belum bisa memproduksi sendiri sehingga dari jasa konveksi mengambil dari pihak eksternal atau tengkulak khusus kain yang di cari keperluan untuk membuat baju seperti halnya kain cotton combad $30 \mathrm{~s}$ yang biasa untuk dibuat menjadi baju. Dan didalam struktur organisasi yang ada pada @anfcreativ.id ini memiliki beberapa karyawan yang mana karyawan tersebut memiliki tempat tinggal di dekat lokasi UMKM ini sehingga bisa membantu dan mempertahankan perekonomian di daerah lokal tersendiri dengan memperkerjakan masyarakat sekitarnya yang mana bisa terus memberikan kontribusi untum memproduksi produk daripada@anfcreative.id.

Dalam hal produksi jasa konveksi ini juga sudah memiliki alat mesin untuk menyetak baju atau baju yang sudah jadi akan di berikan sablon sesuai permintaan dari konsumen. Sehingga disini dimudahkan oleh mesin percetakan sablon untuk baju, jadi karyawan tidak kesusahan untuk meproduksinya. Disamping itu managing director yang mana bertugas untuk menyesuaikan dan memberikan arahan terkait dengan pemesan baju sesuai dengan keingin konsumen, setelah meneriman keinginan konsumen sesuai dengan akad membayarkan uang muka setengah dan akan diberikan kuwintansi atau bukti pembayaran yang sah sehingga bisa diproses pesanan tersebut. Pesanan dari konsumen akan disalurkan kepada karyawan lain yakni seperti penjahit dan pencetak baju baik dari segi jumlah dan desain yang harus diproses sesuai permintaan konsumen agar memunculkan kepuasan konsumen dalam pemesanan produk.

Waktu dalam produksi ini tergantung pada banyaknya jumlah pemesanan yang mana sangat diefesiensikan terhadap deadline sesuai jumlah pemesanan. Seperti halnya pemesanan 100 unit baju bisa diselesaikan dalam kurun waktu kurang lebih 1 hingga 2 minggu. Konsumen bisa melakukan transaksi pelunasan biaya pembuatan kaos pada saat kaos sudah jadi secara kesuluruhan, sesuai dari keinginan pelanggan ingin di kirim via jasa kurir pengiriman atau dikirim secara langsung dengan catatan dalam lingkup Kabupaten Jombang.

\section{b. Situasi konsumen saat pandemi}

Perilaku konsumen ialah studi tentang bagaimana individu, kelompok, dan organisasi memilih, membeli, menggunakan dan bagaimana barang, jasa, ide atau pengalaman untuk memuaskan kebutuhan keinginan mereka (Kotler \& Keller, 2009). Berkaitan dengan pengertian tesebut kondisi saat ini yakni covid-19 terus melanda sehingga diikuti dengan adanya sosial distancing yang mana memunculkan perilaku konsumen baru, yang mana semua aktivitas dilakukan di dalam rumah baik bekerja ataupun transaksi jual beli guna untuk menjaga diri dari tertularnya virus covid-19. Banyak yang merasakan dan mayoritas semua elemen atau pelaku usaha merasakan dampak yang sangat parah ini sehingga megalami penurunan omset secara drastis. 
Walaupun diadakannya kebijakan sosial distancing guna untuk memutus mata rantai covid-19 para konsumen juga harus bertahan hidup dengan bekerja dirumah dan melakukan aktivitas lainnya didalam rumah. Hal ini tidak membuat ciut mental para konsumen melainkan dalam prinsip bertahan hidup mereka harus membeli bahan pokok dan bahan keinginan lainnya. Sehingga pada saat pandemi keinginan untuk belanja masih terus meningkat yang mana bisa menggunakan media via online baik membeli produk yang diinginkan atau konsumi yang lainnya.

Dalam hal konsumen, @anfcreative.id terus meningkatkan pelayan yang baik terhadap konsumen dengan cara berkomunikasi yang baik yang mana UMKM ini juga memiliki lapak di media sosial dan media online tau ecommerce sehingga biasa memudahkan konsumen yang sedang berkativitas dirumah dengan melakukan transaksi yang diinginkan oleh konsumen kepada @anfcreative.id. Setelag itu dalam melakukan pemabayan juga sudah dipemudah oleh teknologi dengan internet banking yang sudah disediakan oleh UMKM @anfcreative.id sehingga semua bisa dibayarkan disana dengan mudah dan bisa memulai transaksi.

\section{c. Strategi pemasaran @anfcreative.id pada saat pandemi}

Pemasaran disini dapat diartikan fungsi dari serangkaian proses guna menciptakan, mengkomunikasikan dan memberikan pelayanan yang sangat baik kepada pelanggan dimana hal ini mempunya tujuan yakni menjalin hubungan baik dengan pelanggan atau konsumen agar dapat menguntungkan perusahaan dan pemangku kepentingan. Darmanto (2016) mendefinisikan pemasaran itu sebuah proses dan manajerial ketika individuk atau kelompok mendapatkan kebutuhan yang mereka inginkan dengan membuat penawaran dan menukarkan produk serta jasa yang mempunyai nilai dengan pihak lainnya. Dalam pernyataan dari para ahli terkait dengan pemasaran UMKM jasa konveksi @anfcreative.id menerapkan proses pemasaran dengan memanjemen secara maksimal, sehingga seperti pada struktur organisasi yang ada di dalam UMKM ini seuai dengan tugas masing-masing.

Dalam hal ini managing director bertugas untuk mengelola dan memasarkan sebuah produk hasil dari @anfcreative.id. Pada saat pandemi seperti ini yang mana telah diketahui bahwa konsumen mulai bergeser pola pikirnya pada aslinya bisa berjualan atau membeli sesuatu dengan secara langsung, tetapi pada saat ini diberlakukan sosial distancing sehingga konsumen hanya bisa berdiam diri dirumah dan tidak bisa melakukan transaksi apapun secara langsung. Menurut Tarigan (2009) digital marketing atau pemasaran digital ialah kegiatan pemasaran branding (pengenalan merek) yang menggunakan berbagai media berbasis web seperti blog, website, email, adwords, ataupun jejaring sosial. Oleh sebab itu @anfcreative.id memiliki gagasan yang mana bukan pada saat pandemi tetapi jauh sebelum saat pandemi ini melanda sudah menerapkan strategi pemasaran secara online dengan menggunakan sosial media marketing seperti Whatsapp, Instagram, dan facebook (Rusmanto, 2017). Dan juga memiliki e-commerce lapak usaha di media online seperti Shopee sehingga ini merupaka peluang yang sangat besar untuk bisa terus mengembang sebuah bisnis UMKM ini dalam situasi pandemi. Sebagian bagian 
kegiatan pemasaran dengan menggunakan media internet, iklan online (periklanan di internet) menjadi pilihan yang menarik para marketer khususnya dan dunia usaha umumnya (Dianati, 2007). Seperti halnya mulai dari penataan feed pada media sosial dan komunikasi dengan baik dengan konsumen ini menjadi tolak ukur keberhasilan untuk meraih pangsa yang sangat besar dan luas walaupun lingkupnya masih UMKM tetapi sudah bisa eksport ke seluruh Indonesia dengan menggunakan strategi marketing media online.

Dengan adanya strategi pemasaran yang dipaparkan oleh @anfceative.id yang mana agar bisa di kenal lebih banyak oleh khalayak umum atau masyarakat umum yang lebih luas, dan juga bisa membantu perekonomian pada saat pandemi. Walaupun saat ini juga banyak sekali saingan jasa konveksi diluar sana yang kurang lebih sama dengan@anfcreative.id, tetapi hal ini tidak menjadi hambatan untuk terus mengedepankan kualitas produk, harga yang bersaing, pelayanan yang terbaik dan memperhatikan kepuasan pelanggan. Berikut ini ialah rincian mengenai faktor internal (kekuatan, kelemahan) dan faktor eksternal (peluang dan tantangan) dalam analisis SWOT yang peneliti sudah rangkum melalui hasil wawancara dan observasi di UMKM jasa konveksi @anfcreative.id sebagai berikut (Nurfayi, 2021). Analisis ini berperan sebagai alat untuk meminimalisasi kelemahan yang terdapat dalam suatu perusahaan atau organisasi serta menekan dampak ancaman yang timbul dihadapi (Mariantha, 2018).

Tabel 1

Tabel IFAS (Internal Factors Analisys Summary)

1. Kekuatan (Strength)

\begin{tabular}{|c|c|c|c|c|}
\hline No. & Kekuatan (Strength) & Bobot & Skor & Nilai Skor \\
\hline 1. & $\begin{array}{l}\text { @ anfcreative.id menjual produk } \\
\text { yang kekinian, harga yang } \\
\text { terjangkau, juga kualitas yang } \\
\text { terjamin }\end{array}$ & 0,2 & 3 & 0,6 \\
\hline 2. & $\begin{array}{l}\text { @ anfcreative.id memiliki jaringan } \\
\text { kerja yang luas }\end{array}$ & 0,1 & 4 & 0,4 \\
\hline 3. & $\begin{array}{l}\text { @ anfcreative.id memiliki lapak } \\
\text { offline dan didalamnya alat yang } \\
\text { sangat lengkap untuk hal produksi }\end{array}$ & 0,3 & 3 & 0,9 \\
\hline 4. & $\begin{array}{l}\text { @ anfcreative.id dalam penjualan bisa } \\
\text { melakukan kredit tempo dengan } \\
\text { pembayaran cicilan setengah dari } \\
\text { akad dan pelunasan di akhir. }\end{array}$ & 0,2 & 4 & 0,8 \\
\hline 5. & $\begin{array}{l}\text { @ anfcreative.id mempunyai citra } \\
\text { produk yang baik dimata konsumen, } \\
\text { seperti melakukan transaksi berkali- } \\
\text { kali karena kepercayaan konsumen } \\
\text { dengan pihak UMKM. }\end{array}$ & 0,2 & 3 & 0,6 \\
\hline & Sub Total & 1 & & 3,3 \\
\hline
\end{tabular}

(Nurfayi, 2021) 
2. Kelemahan (Weaknesses)

\begin{tabular}{clccc}
\hline No. & \multicolumn{1}{c}{ Kelemahan (Weaknesses) } & Bobot & Skor & Nilai Skor \\
\hline 1. & $\begin{array}{l}\text { Letak lapak offline kurang strategis } \\
\text { jauh dari keramaian. }\end{array}$ & 0,3 & 2 & 0,9 \\
\hline 2. & $\begin{array}{l}\text { Masih belum bisa produksi kain } \\
\text { sendiri sehingga membutuhkan } \\
\text { pihak luar untuk mengirimkan kain } \\
\text { agar bisa diproduksi. }\end{array}$ & 0,4 & 3 & 1,2 \\
\hline 3. & $\begin{array}{l}\text { Produk yang ditawarkan masih } \\
\text { terbatas yakni seperti baju formal } \\
\text { atau pakaian dinas masih belum } \\
\text { bisa diproduksi. }\end{array}$ & 0,3 & 1 & 0,3 \\
& Sub Total & & \\
\hline
\end{tabular}

(Nurfayi, 2021)

Dari hasil analisis tabel faktor kekuatan (strenght) memempunya total nilai 3,3 sedangkan kelemahan (weaknesses) total nilai 2,4.

Tabel 2

Tabel EFAS (Eksternal Factors Analisys Summary)

3. Peluang (Opportunities)

\begin{tabular}{clccc}
\hline No. & Peluang (Opportunities) & Bobot & Skor & Nilai Skor \\
\hline 1. & Pangsa pasar yang jelas & 0,3 & 3 & 0,9 \\
\hline 2. & $\begin{array}{l}\text { Bekerjasama dengan pihak luar } \\
\text { untuk pengiriman kain atau } \\
\text { pemesanan kain }\end{array}$ & 0,2 & 4 & 0,8 \\
\hline 3. & $\begin{array}{l}\text { Menerima permintaan produk dari } \\
\text { konsumen atau yang diinginkan } \\
\text { konsumen }\end{array}$ & 0,2 & 3 & 0,6 \\
\hline 4. & $\begin{array}{l}\text { Mengikuti ajang event sesama jasa } \\
\text { konveksi sebagai media promosi }\end{array}$ & 0,1 & 2 & 0,2 \\
\hline 5. & $\begin{array}{l}\text { SDM karyawan yang mumpuni } \\
\text { dengan bidangnya dan lokasi rumah } \\
\text { karyawan disekitar tempat produksi } \\
\text { @anfcreative.id }\end{array}$ & 0,2 & 3 & 0,6 \\
\hline & Sub Total & 1 & 3,1 \\
\hline
\end{tabular}

(Nurfayi, 2021) 
4. Ancaman (Threats)

\begin{tabular}{clccc}
\hline No. & \multicolumn{1}{c}{ Ancaman (Threats) } & Bobot & Skor & Nilai Skor \\
\hline 1. & $\begin{array}{l}\text { Semakin banyak pesaing UMKM } \\
\text { yang baru dan lebih kreatif juga } \\
\text { inovatif. }\end{array}$ & 0,2 & 3 & 0,6 \\
\hline 2. & $\begin{array}{l}\text { Pengiriman barang dengan jasa } \\
\text { kerjasama dipihak yang sama } \\
\text { dengan bisnis lain }\end{array}$ & 0,3 & 2 & 0,6 \\
\hline $3 . \quad \begin{array}{l}\text { Lapak offline yang dekat dengan } \\
\text { keramaian sehingga pangsa } \\
\text { pasarnya lebih banyak. }\end{array}$ & 0,4 & 2 & 0,8 \\
\hline Banyaknya pasar baru yang sudah \\
$\begin{array}{l}\text { dilayani dalam satuan bisnis yang } \\
\text { sama. }\end{array}$
\end{tabular}

(Nurfayi, 2021)

Pada tabel tersebut menunjukkan bahwasannya untuk faktor peluang (Opportunities) niali skornya 3,1 dan faktor ancaman (Threats) 2,3. Selanjutnya nilai total skor setiap faktor dapat dirincikan yakni, kekuatan (strength): 3,3, kelemahan (weaknesses): 2,4, peluang (opportunities): 3,1, dan ancaman (threats) 2,3.

Jika dalam hal ini diketahu nilai dari kekuatan diatas nilai kelemahan selisih (+) 0,9 dan peluang dengan ancaman selisih (+) 0,8. Dari hasil identifikasi faktor ini maka dapat digambarkan dalam diagram analisis SWOT sebagai berikut.

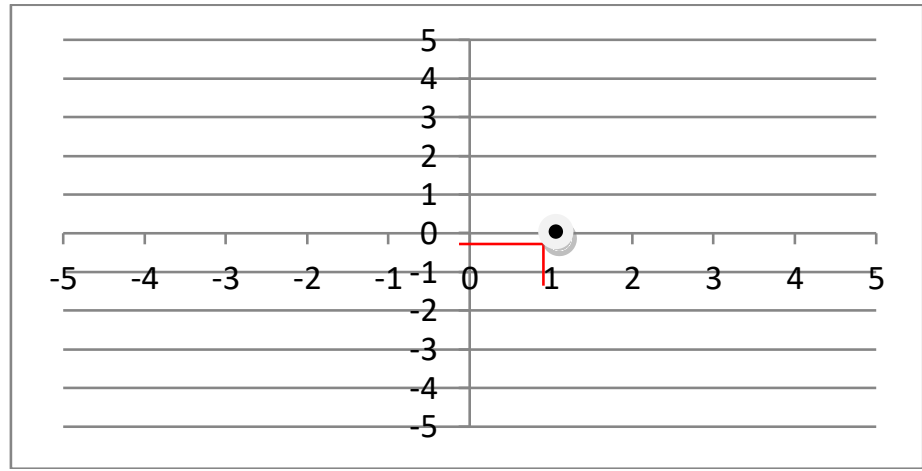

\section{Gambar 1}

Gambar diagram SWOT

Dari hasil yang ditunjukan diatas bahwa @anfcreative.id masuk pada kuadran (positif,positif). Posisi ini mendandakan bahwa@anfcreative.id dalam kondisi yang kuat dan berpeluang di era pandemi ini, sehingga sangat memungkinkan untuk terus melakukan ekspansi memperluas pangsa pasar dan bisa membantu perekonomian di kala pandemi. 
Tabel 3

Tabel diagram analisis SWOT

\begin{tabular}{|c|c|c|}
\hline IFAS & $\begin{array}{l}\text { Kekuatan } \\
\text { (Strength) }\end{array}$ & $\begin{array}{c}\text { Kelemahan } \\
\text { (Weaknesses) }\end{array}$ \\
\hline \multicolumn{3}{|l|}{ EFAS } \\
\hline $\begin{array}{c}\text { Peluang } \\
\text { (Opportunities) }\end{array}$ & $\begin{aligned} & \text { Strategi SO } \\
= & 3,3+3,1 \\
= & 6,4\end{aligned}$ & $\begin{aligned} & \text { Strategi WO } \\
= & 2,4+3,1 \\
= & 5,5\end{aligned}$ \\
\hline $\begin{array}{l}\text { Ancaman } \\
\text { (Threats) }\end{array}$ & $\begin{aligned} & \text { Strategi ST } \\
= & 3,3+2,3 \\
= & 5,6\end{aligned}$ & $\begin{aligned} & \text { Strategi WT } \\
= & 2,4+2,3 \\
= & 4,7\end{aligned}$ \\
\hline
\end{tabular}

(Nurfayi, 2021)

Dari tabel tersebut bisa disimpulkan bahwasannya kekuatan + peluang atau strategi $(\mathrm{SO})=6,4$. Peluang + kelemahan atau strategi $(\mathrm{WO})=5,5$. Kekuatan + ancaman atau strategi $(\mathrm{ST})=5,6$. Dan untuk kelemahan + ancaman $(\mathrm{WT})=4,7$. Sehingga dalam perencanaan strategi SO yang memiliki nilai 6,4 kemudian ST, WO, dan yang terakhir yakni WT.

Tabel internal dan eksternal ini digunakan untuk menentukan posisi UMKM yang didasarkan analisis total skor bahwa faktor kekuatan dan peluang lebih tinggi memiliki skor dibandingkan dengan faktor kelemahan dan ancaman. Sehingga merupakan posisi dengan strategi SO bisa dikatakan sangat menguntungkan bagi UMKM yang mempunya peluang juga kekuatan lebih besar dan dapat dimanfaatkan peluang yang ada secara maksimal agar bisa terus membuka lapangan pekerjaan sehingga bisa membantu perekonomian masyarakat ditengah pandemi ini, juga menerapkan strategi yang mendukung pola strategi SO.

\section{Kesimpulan}

Berdasarkan hasil analisis IFAS dan EFAS atau faktor internal dan eksternal bahwa diketahui ada banyak macam kekuatan, kelemahan, peluang dan ancaman. Setelah dilakukan analisis ini mendapatkan hasil bahwa skor nilai tertinggi yakni berada pada strategi SO yang memiliki nilai 6,4 kemudian disusul oleh strategi ST memiliki nilai 5,6, setelah itu dilanjut oleh strategi WO yakni dengan nilai skor 5,5, dan yang paling terakhir yakni strategi WT dengan skor nilai 4,7. Hal ini menempatkan posisi UMKM pada strategi SO menunjukan bahwa UMKM ini bisa terus berkembang. Posisi ini menjadi acuan dalam kuadran satu yakni strategi agresif dimana strategi ini bisa terus menerapkan hal-hal yang postif guna untuk memperluas pangsa pasar dan membantu perekonomian di saat pandemi, posisi yang strategis ini juga yang dapat dilakukan ialah melakukan ekspansi pangsa pasar atau pengembangan market seluasluasnya dan memperkerjakan karyawan yang tempat tinggalnya berada didekat lokasi produksi UMKM jasa konveksi sehingga ekonomi rumah tangga akan terus bertahan di era pandemi. Analisis SWOT menghasilkan beberapa saran rekomendasi strategi yang bisa dilakukan dalam pengembangan UMKM jasa konveksi @anfcreative.id yakni : 
1. Memperluas pangsa pasar dan jaringan pemasaran juga bekerjasama dengan pihak yang bisa membuat UMKM ini terus berkembang

2. Mengembangkan sistem manajemen dalam organisasi UMKM agar bisa membuat cabang-cabang usaha yang lebih luas.

3. Menciptakan produk yang bekualitas, harga bersaing, dan kemudahan dalam pencarian produk tersebut untuk konsumen.

4. Bekerja sama dengan lembaga UMKM yang lain atau bermitra untuk kepentingan bersama.

5. Terus menciptakan lapangan perkerjaan untuk masyarakat sekitar, agar membantu dalam penghasilan ekonomi rumah tangga para karyawan dan bisa menghidupi keluarganya juga bertahan di saat pandemi seperti ini.

6. Dan untuk peneliti yang selanjutkan agar terus menganalisis dengan menggunakan analisis SWOT untuk menemukan kekuatan, kelemahan, peluang dan tantangan yang ada di setiap UMKM maupun perusahaan sehingga bisa terus menemukan strategi yang baru dalam bersaing di pasar. 


\section{BIBLIOGRAFI}

Ahmad, D. (2000). Metode Penelitian Agama: Prespektif Ilmu Perbandingan Agama. Bandung: Pustaka Setia.

Darmanto, S. W. (2016). Manajemen Pemasaran Untuk Mahasiswa, Usaha Mikro, Kecil dan Menengah. Yogyakarta: Deepublish.

Dianati, A. (2007). 6 Rahasia Sukses Menjadi Jutawan Internet. Jakarta: Media Kita.

Fahmi, I. (2015). Manajemen Strategic. Bandung: Alfabeta.

Jatmika, R. T. (2017). Masalah yang dihadapi Usaha Kecil Menengah di Indonesia. Jurnal El-Ecosy, 2(6), 1-14.

Jazuli, S. (2016). Analisis SWOT Strategi Pemasaran Produk Pembiayaan pada BMT El-Syifa Cigajur. Skripsi. UIN Syarif Hidayatullah.

Kotler, P., \& Keller, K. L. (2009). Manajemen Pemasaran (13 ed.; B. Sabran, Ed.). Jakarta: Erlangga.

Mariantha, N. (2018). Manajemen Biaya. Makasar: Celebs Media Perkasa.

Marimin. (2004). Teknik dan Aplikasi Pengambilan Keputusan Kriteria Majemuk. Surabaya: Grasindo.

Muhsy, N. (2020). Mengulas Pengertian Produk Menurut Para Ahli Beserta Rinciannya. Diambil 25 Desember 2020, dari https://trifaris.net/pengertian-produkmenurut-para-ahli/

Nurfayi, A. (2021). Wawancara Seputar @anfcreative.id. (A. J. Winarto, Interviewer).

Purwanto, N. P. (2020). Bantuan Fisikal Untuk UMKM Pada Masa Pandemi Covid-19. Puslit BKD 12(17), 19-24.

Rangkuti, F. (2008). The Power of Brands. Jakarta: Gramedia.

Rusdiansyah. (2016). Analisis Strategi Aplikasi Penagihan dengan Metode SWOT. Bina Insani ICT Journal, 3(1), 145-153.

Rusmanto. (2017). Modul Praktikum Manajemen Pemasaran Berbasis IT. Jakarta: STT Nurul Fikri.

Sugiyono. (2011). Metode Penelitian Kuantitatif, Kualitatif, dan R\&D. Bandung: Alfabeta.

Tarigan, R. S. (2009). Creative Digital Marketing Teknologi Berbiaya Murah, Inovatif dan Berdaya Hasil Gemilang. Jakarta: Elsa Media Koputindo. 